\title{
BANTAL SIU PADA UPACARA \\ PAWIWAHAN DI KELURAHAN BALER BALE AGUNG KECAMATAN NEGARA KABUPATEN JEMBRANA
}

\author{
I Gusti Ayu Ngurah \\ Ni Ketut Caturadi Mahyuni \\ mahyuni@yahoo.com \\ Fakultas Ilmu Agama, Seni dan Budaya \\ Universitas Hindu Indonesia
}

\begin{abstract}
ABSTRAK
Artikel ini membahas tentang sarana upacara dalam bentuk bebantenan bantal siu pada upacara pawiwahan di Kelurahan Baler Bale Agung, Kecamatan Negara Kabupaten Jembrana. Banten ini memiliki keunikan dan berbeda dengan daerah lain, namun tetap mengacu pada ajaran Agama Hindu. Topik yang akan dikaji yakni tentang bentuk dan fungsi banten Bantal Siu ini pada upacara pawiwahan. Penelitian ini bersifat kualitatif, pengumpulan data dilakukan dengan wawancara lapangan, studi dokumen dan observasi. Dari analisis hasil data, maka hasil penelitian yang didapat yaitu: 1) Bentuk Banten Bantal Siu yang digunakan di Kelurahan Baler Bale Agung dalam prosesi mempelai berdua melaksanakan pengraos (pala dara). 2) Dalam Banten Bantal Siu digunakan beberapa fungsi, yaitu: fungsi religi, fungsi sosial, fungsi estetika, dan fungsi pendidikan.
\end{abstract}

Kata Kunci: Banten Bantal Siu, Pawiwahan

\begin{abstract}
This article discusses of bantal siu at a ceremony in Baler Bale Agung Village, Negara District of Jembrana Regency. Banten is unique and different from other regions, but still refers to the teachings of Hinduism. The topic that will be studied is about the shape and function of the bantal siu at a pawiwahan ceremony. This research is qualitative, data collection is done by field interviews, document studies and observations. From the analysis of the results of the data, the research results obtained are: 1) The shape of the Banten Bantal Siu is used in the Baler Bale Agung Village in the procession of the bride and groom carrying out the nutmeg. 2) Banten Bantal Siu several functions are have, namely: religious function, social function, aesthetic function, and education function.
\end{abstract}

Keywords: Banten Bantal Siu, Pawiwahan 


\section{PENDAHULUAN}

Agama Hindu adalah agama yang bersifat universal. Maksudnya adalah adat istiadat, tradisi dan budaya yang menyertai setiap pelaksanaan ritual keagamaan merupakan suatu media untuk menyampaikan ajaran agama Hindu. Strategi agama yang universal tidak menentang munculnya kepercayaankepercayaan atau agama-agama tetapi berusaha menyuburkan kepercayaan yang telah berkembang. Hal ini merupakan salah satu alasan bahwa ajarannya mudah diterima oleh masyarakat diberbagai belahan dunia.

Sidartha (dalam Karda, 2007:16) menyatakan sebagaimana halnya rumah yang memiliki kerangka, demikian juga agama Hindu pun mempunyai kerangka dasar berjumlah tiga yaitu : 1, Pengetahuan filosofis (tattwa), 2. Susila (etika), 3. Upacara (ritual). Walaupun terbagi menjadi tiga tapi pada kenyataannya mereka itu terjalin menjadi satu kesatuan. Ketiganya tidak berdiri sendiri, tetapi merupakan satu kesatuan yang harus dilaksanakan oleh umat Hindu. Jika filsafat agama saja diketahui tanpa melaksanakan ajaran susila dan upacara tidaklah sempurna. Demikian juga halnya melakukan upacara saja tanpa dasar filsafat dan etika percuma pulalah upacara itu. Bagaikan seluruh badan yang tak dapat dipisahkan membentuk manusia yang sempurna.

Lebih lanjut Wiana (dalam Karda, 2007 : 16 ) menyatakan bahwa nilainilai Weda itu dirumuskan menjadi tattwa (pengetahuan) hidup yang dijabarkan kedalam konsep bersama menjadi petunjuk hidup yang bersusila (etika) untuk membangun manusia bermoral luhur dan bermental tangguh. Menanamkan nilainilai tersebut dalam lubuk hati sanubari umat manusia ada yang dilakukan melalui upacara-upacara yadnya (ritual). Kitab Upadesa menyebutkan bahwa Agama Hindu diumpamakan seperti telur, tattwa ibarat kuning telur, susilanya ibaratnya putih telur dan telur ibarat upacara. Ini artinya yadnya sebagai pembungkus susila dan tattwanya, karena itu upacara mempunyai kedudukan yang sangat tinggi dalam kehidupan beragama Hindu.

Mencermati tentang isi kerangka dasar Agama Hindu yang terdiri dari Tattwa, Etika dan Upacara yang merupakan suatu kesatuan yang tidak dapat dipisah-pisahkan satu sama yang lainnya. Segala aktivitas yang dilakukan oleh umat Hindu mencangkup tiga kerangka dasar tersebut. Misalnya dalam satu rangkaian upacara atau yadnya diperlukan pemikiran yang matang demi terlaksananya yadnya tersebut. Dalam yadnya ada etika mengikat setiap orang yang terlibat di dalamnya untuk mengendalikan diri. Kemampuan dalam mengendalian diri diyakini sangat berpengaruh terhadap pelaksanaan yadnya.

Salah satu cara untuk memperoleh pemahaman tentang adanya Agama Hindu secara mendalam dapat dilakukan dengan mempelajari kitab-kitab suci Hindu. Dalam mempelajari tidak dapat merujuk langsung pada kitab suci veda, melainkan dilakukan secara bertahap. Pada sisi lainnya jika umat telah memahami makna suatu upacara agama, termasuk tata cara pelaksanaan upacara sudah terlaksanakan secara sistematis, tetapi jika materi upacara agama itu diperoleh dengan cara tidak baik, misalnya bahan-bahan untuk keperluan yadnya didapatkan dari hasil curian, hasil dari perilaku kotor atau leteh, sarana yang dipergunakan merupakan hasil dari perbuatan curang, maka yadnya yang demikian adalah yadnya 
yang tidak baik atau tamasika yadnya. Jadi upacara agama itu mestinya dilandasi oleh kesucian yang utuh.

Umat Hindu mempunyai tujuan hidup yang disebut Catur Purusa Artha yaitu Dharma, Artha, Kama, dan Moksa. Hal ini tidak bisa diwujudkan sekaligus tetapi secara bertahap. Tahapan untuk mewujudkan empat tujuan hidup itu disebut dengan Catur Asrama. Pada tahap Brahmacari asrama tujuan hidup diprioritaskan untuk mendapatkan Dharma. Grhasta Asrama memprioritaskan mewujudkan artha dan kama. Sedangkan pada Wanaprasta Asrama dan Sanyasa Asrama tujuan hidup diprioritaskan untuk mencapai moksa.

Pawiwahan adalah suatu upaya untuk mewujudkan tujuan hidup Grhasta Asrama, tugas pokok dari Grhasta Asrama menurut lontar Agastya

Parwa adalah mewujudkan suatu kehidupan yang disebut "Yatha sakti Kayika Dharma" yang artinya dengan kemampuan sendiri melaksanakan Dharma. Jadi seorang Grhasta Asrama harus benar-benar mampu mandiri mewujudkan Dharma dalam kehidupan ini. Kemandirian dan profesionalisme inilah yang harus benarbenar disiapkan oleh masyarakat Hindu yang ingin menempuh jenjang perkawinan.

Perkawinan adalah ikatan suci atau komitment seumur hidup menjadi suami-istri dan merupakan ikatan sosial yang paling kuat antara laki laki dan wanita. Pawiwahan juga merupakan sebuah cara untuk meningkatkan perkembangan spiritual. Lelaki dan wanita adalah belahan jiwa, yang melalui ikatan pernikahan dipersatukan kembali agar menjadi manusia yang seutuhnya karena di antara keduanya dapat saling mengisi dan melengkapi. Pawiwahan harus berdasarkan pada rasa saling percaya, saling mencintai, saling memberi dan menerima, serta saling berbagi tanggungjawab secara sama rata, saling bersumpah untuk selalu setia dan tidak akan berpisah serta disahkan secara hukum dalam bentuk Akta Perkawinan, Sesuai dengan Undang-Undang No. 1/1974. Akta Perkawinan itu dicatatkan pada Kantor Catatan Sipil didelegasikan kepada Kepala Kecamatan.

Dalam perkawinan ada dua tujuan yaitu artha dan kama yang berdasarkan dharma. Pada tahap persiapan, seseorang yang akan memasuki jenjang perkawinan amat membutuhkan bimbingan, khususnya agar dapat melakukannya dengan sukses atau memperkecil rintangan-rintangan yang mungkin timbul. Bimbingan tersebut akan lebih baik kalau diberikan oleh seorang yang ahli dalam bidang Agama Hindu, terutama mengenai tugas dan kewajiban seorang Grhasta untuk bisa mandiri didalam mewujudkan tujuan hidup mendapatkan artha dan kama berdasarkan dharma. Menurut Ninian Smart (dalam Agung Paramita, 2018: 40) ada tujuh dimensi setiap agama. Salah satu dimensi yang penting adalah dimensi praktisritual. Dalam aktivitas beragama umat Hindu di Bali dimensi praktis ritual ini tercermin melalui banten.

Banten yang digunakan sebagai pelengkap dalam melaksanakan upacara Pawiwahan yaitu disebut dengan Banten Bantal Siu pada Upacara Pawiwahan. Adapun keunikan dari Banten Bantal Siu pada upacara Pawiwahan di Baler Bale Agung yaitu ketika proses atau pelaksanaan Tri Upasaksi, yang disebut dengan Dewa Saksi, Manusia Saksi dan Bhuta Saksi. Dewa Saksi dan Bhutha Saksi adalah kesaksian secara Niskala. Kesaksian Niskala merupakan kesaksian yang dilaksanakan dalam bentuk upacara keagamaan. Sedangkan Manusia Saksi adalah 
kesaksian secara Sekala yang dilaksanakan oleh prajuru adat dan dinas yaitu Bendesa Adat, Kelian Banjar Adat dan Kelian Dinas serta keluarga kedua belah pihak mempelai.

Di dalam sistem pelaksanaan upacara Pawiwahan satu daerah dengan daerah lain di Bali pada prinsipnya adalah sama walaupun pelaksanaannya yang berbeda sesuai dengan Desa (tempat), Kala ( waktu ), dan Patra (keadaan). Pelaksanaannya dilandasi desa, kala, patra ini melahirkan kegiatan di Bali khususnya di Banjar Pekraman yang akhirnya menjadi tali kendali pada setiap aktivitas yang dilakukan secara turun temurun, dari generasi ke generasi berikutnya dan juga sebagai suatu kewajiban ini lambat laun menjadi budaya agama. Maka dari itu dalam mengesahkan Pawiwahan di Kelurahan Baler Bale Agung, Kecamatan Negara, Kabupaten Jembrana diperlukan Banten Bantal Siu yang digunakan dalam proses perkawinan yang bertujuan mempelai berdua mengetahui bahwa menjalankan perkawinan itu penuh dengan cobaan dan rintangan.

\section{Metode Penelitian}

Lokasi penelitian merupakan sasaran menentukan tempat dalam penelitian, sebagai tempat pengkajian dari suatu penelitian yang dilakukan. Adapun penelitian yang dilakukan di Kelurahan Baler Bale Agung, Kecamatan Negara, Kabupaten Jembrana, dengan bertujuan untuk mengetahui kajian Banten Bantal

Siu. Pemilihan lokasi penelitian ini dilaksanakan atas pertimbangan masalah Banten Bantal Siu yang dirasa unik sebagai warisan turun temurun untuk diketahui dan dikaji, karena belum ada yang pernah meneliti tentang Banten Bantal Siu pada upacara Pawiwahan kelurahan Baler Bale Agung, Kecamatan Negara, Kabupaten Jembrana.

Penelitian ini dirancang dengan pendekatan penelitian kualitatif. Metode pengumpulan datanya meliputi wawancara dengan para tokoh agama dan adat, menelusuri sumber dokumen yang berhubungan dengan tradisi ini, dan melakukan observasi ketika ada upacara pawiwahan yang menggunakan bantal siu. Setelah data terkumpul baru dilakukan analisis deskriptif sesuai dengan hasil wawancara, pengamatan dan studi dokumen.

\section{PEMBAHASAN}

\subsection{Bentuk Banten Bantal Siu Pada Upacara Pawiwahan}

Sesuai hasil wawancara dengan Juli Suarnawa (wawancara, 6 Desember 2019) menyatakan bahwa para leluhur kita sudah sangat bijaksana, dan menyadari bahwa keturunan berada dimana-mana dan dalam keadaan yang berbeda-beda pula. Namun beliau menghendaki agar keturunannya dapat tetap melakukan ajaran-ajaran agama, sesuai dengan tempat, waktu, dan keadaannya, atau sering pula disebut “ desa, kala, dan patra ". Desa diartikan tempat, kala diartikan waktu, keduanya menyebabkan adanya banten yang berbeda-beda seperti sekarang, karena mungkin ditempat itu atau waktu untuk mencari benda-benda tersebut tidak mengijinkan. 
Sedangkan " Patra " (keadaan) umat, menyebabkan adanya banten kecil, sederhana, dan besar. Dalam bahasa bali disebut: Nista, Madya, dan Utama.

Menurut keterangan Juli Suarnawa (wawancara, 6 Desember 2019) bahwa berdasarkan kesadaran dan keikhlasan, disertai dengan hati yang suci bersih, kita bisa memilih untuk membuat atau melakukan yadnya sesuai dengan apa yang ada pada kita. Umpama saja tidak diadakan peraturan-peraturan seperti diatas maka umat yang miskin kalau dipaksakan membuat banten besar sudah tentu tidak mungkin sebaliknya orang kaya, tidaklah pantas membuat banten yang kecil, karena dia telah menerima sesuatu yang berlebihan dari Ida Sang Hyang Widhi Wasa hendaknya dia menunjukkan rasa terima kasihnya sesuai dengan apa yang telah diterima.

Dengan demikian dapatlah dicapai keadilan dan kestabilan dalam kehidupan masyarakat. Seperti kita ketahui bahwa khususnya di Kelurahan Baler Bale Agung, Kecamatan Negara, Kabupaten Jembrana didalam prosesi upacara perkawinan (Pawiwahan). Dalam upacara pengraos (Phala Dara), leluhur umat Hindu khususnya di Kelurahan Baler Bale Agung, Kecamatan Negara, Kabupaten Jembrana meninggalkan kearipan budaya lokal yang penuh nilai religius dan sosial budaya dengan konsep kesederhanaan mengingat masyarakat di Kelurahan Baler Bale Agung, Kecamatan Negara, Kabupaten Jembrana sebagian besar adalah para pendatang (rantauan).

Dari beberapa kota di Bali menurunkan upacara atau upakara yang disebut dengan Banten Bantal Siu yang dijadikan sebagai dasar utama di dalam upacara pengeraos (Phala Dara) dalam rangkaian upacara pawiwahan (Juli Suarnawa, wawancara 6 Desember 2019).

Adapun upakara atau Banten tersebut terdiri dari :

\section{Daksina}

Sunantri (wawancara, 9 Desember 2014) menyatakan sebagai alasnya ada yang menyebut bebedogon, wakul daksina atau serembeng daksina kemudian berturut-turut diisi tampak dara dari busung. Setelah itu diberi sedikit beras, kelapa yang sudah dibersihkan serabutnya, telur itik mentah dan pelawa peselan. Lalu diberi gantungan, bijaratus, pisang mentah, tingkih, pangi, base atau daun sirih tampel. Kemudian dilanjutkan dengan mengisi benang, uang, dan canang payasan masing-masing sebuah atau sebutir. Dan semuanya dialasi dengan kojong tersendiri.

\section{Sodo Putih Kuning}

Sebagai alasnya dipakai tamas, kemudian diisi nasi disebut untek (penek) dua buah yang berwarna putih dan kuning dilengkapi dengan lauk pauk, seperti kacang komak, serundeng atau sesaur, ikan dan garam, sambel. Kemudian dilengkapi dengan raka-raka, buah-buahan dan sampiannya lengkap dengan bunga serta porosannya (Sunantri, wawancara 9 Desember 2014).

Peras 
Sebagai alasnya dipakai sebuah taledan, kemudian berturut-turut dari bawah diisi sedikit beras, uang, beras putih, sirih tampel, aled peras, dari busung, dua buah tumpeng yang ditaruh ditengah-tengah. Dan dibagian hulunya diisi raka-raka, seperti buah-buahan, jajan, tebu, sampiannya disebut sampian tangga atau sampian peras. Sedangkan dibagian hilirnya diisi kojong kurenan yang berisi rerasmen dengan ikannya ikan ayam yang dipanggang (Sunantri, wawancara 9 Desember 2014).

\section{Canang Pengeraos}

Juli Suarnawa (wawancara, 6 Desember 2014) canang pengeraos ini alasnya dipakai sebuah taledan kecil, dan berisi 4 buah kojong yang masingmasing berisi kapur, pinang, gambir, dan susur atau tembakau. Ditengahtengah diisi dua atau atau tiga lembar sirih. Kemudian diatasnya di susun dengan taledan yang berisi dua buah tangkih, masing-masing berisi wija (beras dicuci dan dicampur dengan bunga serta air cendana), disertai minyak wangi disebelah tangkih ini ditambahkan dengan bunga, rokok, dan tidak lupa mengisi korek api.

\section{Canang Pebersihan (Pengeresikan)}

Untuk alasnya dipakai sebuah ceper yang berisi 7 buah tangkih, masingmasing diisi :

1. Sisig yaitu dari beras yang dinyanyah sampai halus.

2. Ambuh yaitu terbuat dari daun kembang sepatu atau bunga yang lain.

3. Kekosok Kuning (penggosok badan) yaitu dari tepung beras dicampur kunir.

4. Kekosok Putih ini terbuat dari tepung beras putih.

5. Tepung Tawar yaitu terbuat dari beras yang direndam dicampur daun kayusakti (dapdap) diisi kunir dan ditumbuk halus.

6. Minyak yaitu kapas dicelupkan kedalam minyak kelapa.

7. Pupur yang adalah bedak bayi.

Kemudian diatas ketujuh buah tangkih dan perlengkapannya itu disusun sebuah canang payasan (Suarningsih, wawancara 8 Desember 2014).

\section{Bantal Siu}

Subagia (wawancara, 12 Desember 2014) sebagai alasnya adalah sebuah paso kuningan, diatas paso kuningan berisi dua buah bantal. Bantal yang satu berisi tujuh belas buah yang diikat ujungnya mengerucut segitiga dihiasi wastra putih, dan satunya lagi berisi enambelas buah diikat ujungnya dibusung tagel dihiasi wastra kuning keduanya dialasi dengan kain wali dan diikat dengan benang tridatu makna dari benang tridatu yaitu tiga unsur kekuatan dari Brahma, Wisnu, dan Siwa. Disampingnya diisi temu-temuan, kelapa dibakar (nyuh metunu), pisang saba dibakar (biu metunu), tipat sirikan, sate lima buah, karangan atau bakaran (pengunyaan) lebih jelas lihat gambar berikut : 


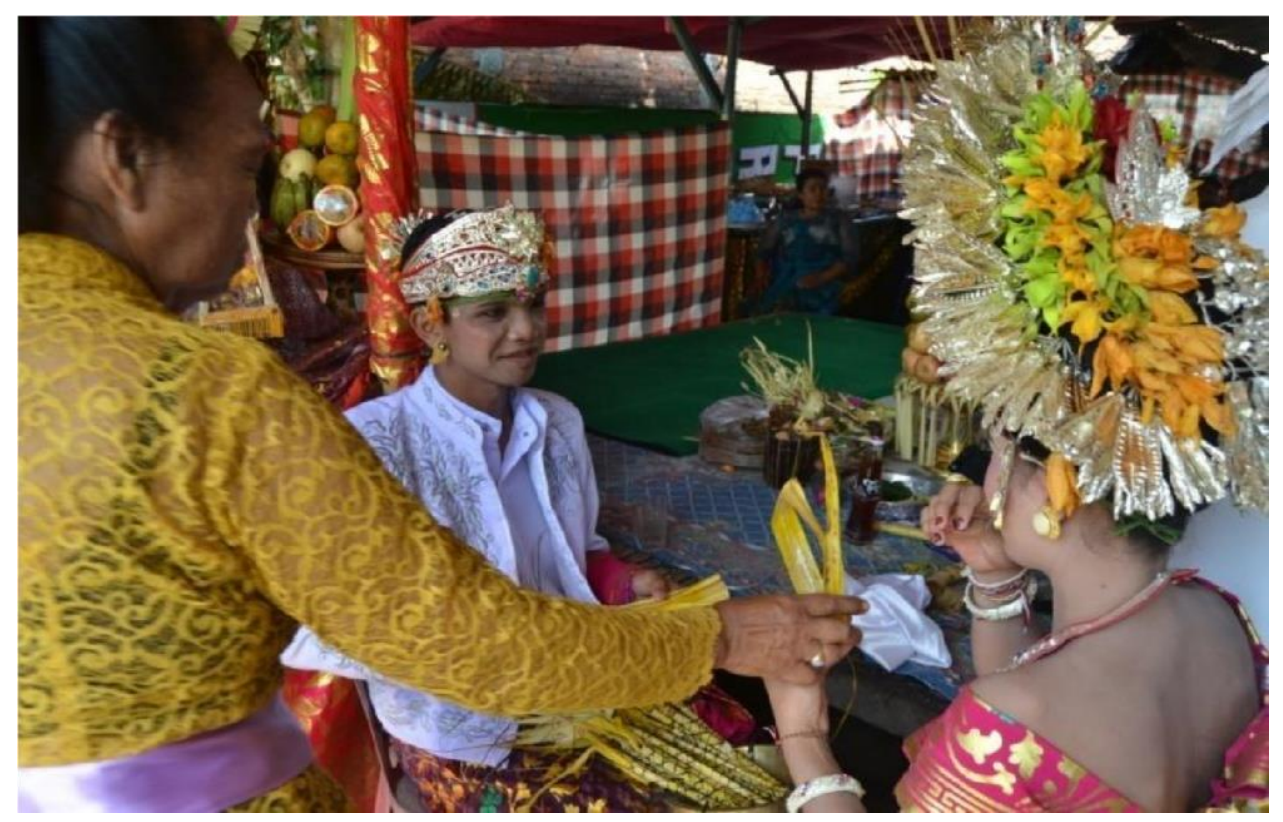

Foto 1

Prosesi kedua mempelai membuka Bantal Siu

(Sumber : Ni Ketut Caturadi Mahyuni, 2019)

\section{Pajegan}

Buah-buahan, jajan, yang disusun mengerucut menyerupai bentuk gunung, diatasnya berisi canang pajegan (Sunantri, wawancara 9

Desember 2019).

\section{Rantasan}

Sunantri (wawancara, 9 Desember 2019) menyatakan sebuah kain putih kuning yang tersusun rapi berbentuk segitiga.

\section{Canang Taksu}

Sunantri (wawancara, 9 Desember 2019) menyatakan sebagai alasnya tamas diatasnya berisi beras, segehan, canang gantal, dan canang sari.

\section{Segehan Agung}

Sebagai alasnya serembeng diatasnya berisi nasi kepel putih tiga buah beralaskan tangkih dan daun kayusakti. Kemudian berisikan sisig ambuh, kelapa gading (Klungah nyuh gading), arak, tuwak, berem, air putih, dan canang genten (Sunantri, wawancara 9 Desember 2019).

\section{Segehan Mancawarna}

Sebagai alasnya dipakai daun atau taledan kecil yang berisi sebuah tangkih pada salah satu ujungnya, untuk tempat lauk pauknya yang terdiri dari bawang merah, garam, dan jahe. Ditengah-tengah taledan itu diisi lima buah nasi yang berwarna putih, merah, kuning, hitam, dan berumbun dan 
diatasnya disusun sebuah canang genten (Sunantri, wawancara 9 Desember 2019).

\section{Tata Cara Menyusun Tempat}

Ariana (wawancara, 21 Desember 2019) adapun tata cara menyusun yaitu sebagai berikut : Tata letaknya dibagi menjadi tiga yaitu hulu, tengah dan teben. Sebagai hulu : daksina, sodo putih kuning, peras dan bantal siu. Diletakkan ditengah : canang pengeraos, pajegan rantasan, pengeresikan dan canang taksu dihadapan pemangku yang muput upacara. Diletakkan diteben ( dibawah ) : segehan agung dan segehan panca warna, lebih jelas lihat gambar berikut.

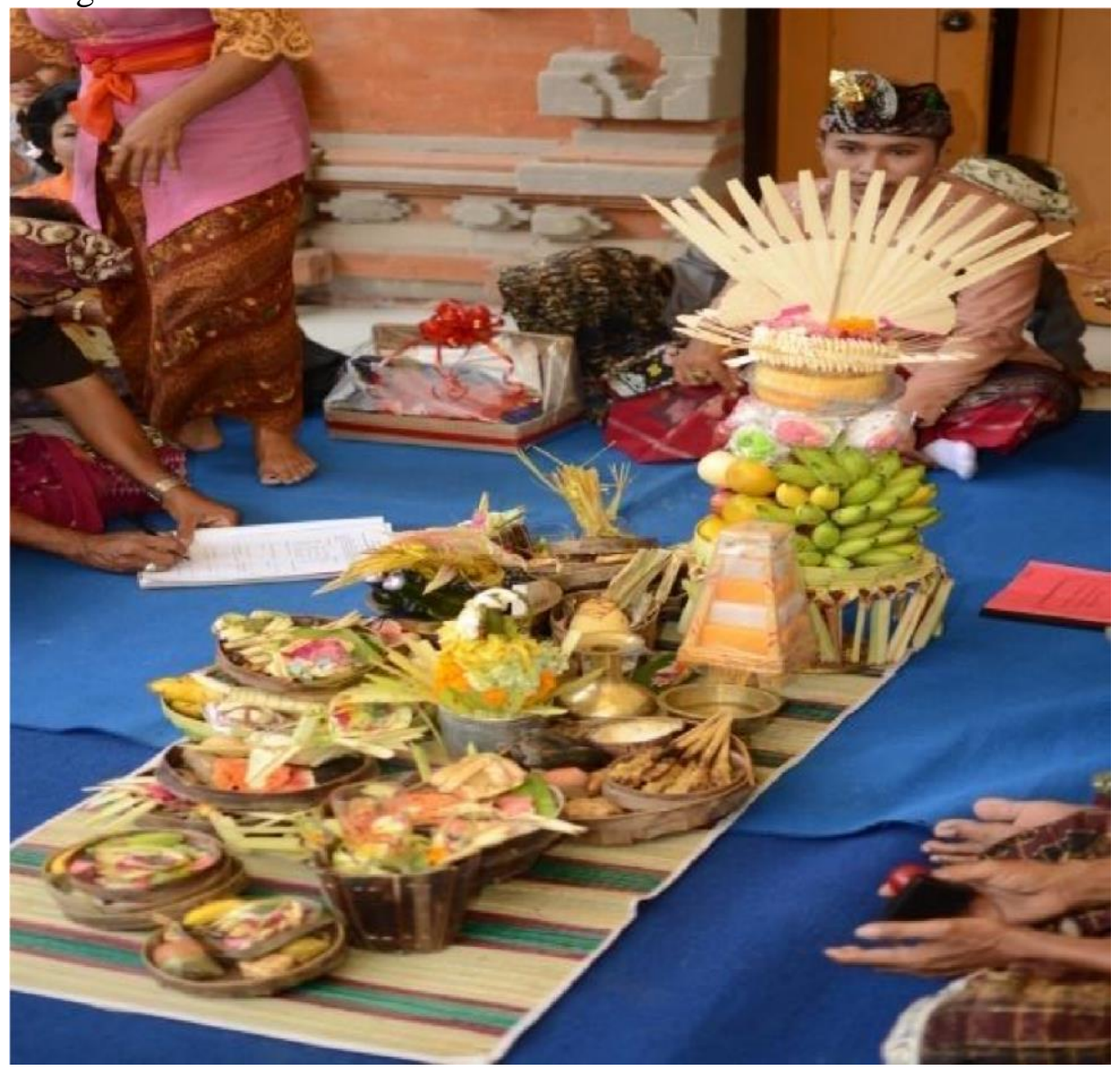

Foto 2

Bentuk Banten Bantal Siu pada saat peminangan

(Sumber : Ni Ketut Caturadi Mahyuni, 2019)

\subsection{Fungsi Banten Bantal Siu Pada Upacara Pawiwahan}

Sesuai dengan hasil wawancara dengan Suardika (Wawancara, 22 Desember 2019) menyatakan bahwa Banten dalam Agama Hindu adalah bahasa agama. Ajaran suci Veda (Sabda Tuhan ) itu disampaikan kepada umat dalam berbagai bahasa. Ada yang menggunakan bahasa tulisan seperti dalam kitab Veda Samhita disampaikan dengan bahasa sansekerta, ada disampaikan dengan bahasa lisan. 
Bahasa lisan ini sesuai dengan bahasa tulisnya. Setelah di Indonesia disampaikan dengan bahasa Jawa Kuno dan di Bali disampaikan dengan bahasa Bali. Isi Veda itu disampaikan juga dalam bahasa mono. Mono artinya diam namun banyak menyampaikan informasi tentang keberadaan Veda. Bahasa Mono itu adalah banten. Karena banten adalah merupakan perwujudan Ida Sang Hyang Widhi Wasa, banten dalam lontar Yadnya Prakerti memiliki tiga fungsi sebagai simbol ritual yang sakral. Dalam lontar tersebut banten disebutkan :

"Sahananing Bebanten Pinaka Raganta Tuwi, Pinaka Warna Rupaning Ida Bhatara, Pinaka Anda Bhuwana "

Dalam lontar ini ada tiga hal yang dibahasakan dalam wujud lambang oleh Banten yaitu :

\section{"Pinaka Raganta Tuwi"}

Terjemahan :

Lambang dirimu atau lambang diri kita.

\section{"Pinaka Warna Rupaning Ida Bhatara"}

Terjemahan :

Lambang kemahakuasaan Tuhan.

\section{"Pinaka Anda Bhuana "}

Lambang alam semesta (Bhuana Agung)

Banten yang termasuk sebagai lambang diri kita yaitu banten tataban alit, banten ini adalah banten peras yang digunakan untuk melaksanakan pengraos (Phala Dara). Dalam upacara pawiwahan lambang perwujudan dan doa untuk mencapai sukses. Untuk meningkatkan jenjang kehidupan diri Brahmacari menuju ke jenjang yang lebih tinggi yaitu Grhasta Asrama. Didunia ini tidak ada manusia normal yang tidak ingin sukses dalam hidupnya. Lalu apa yang harus kita lakukan sebagai syarat minimal agar kita sukses dalam hidup ini.

Dalam banten peras ini digambarkan dengan jelas, penggambaran tersebut sangat sesuai dengan konsep Tattwa Agama Hindu yang tercantum dalam kitab Weda dan Sansekerta. Didalam lontar disebutkan "Peras Ngarania Prasida Tri Guna Sakti " artinya peras namanya adalah sukses (Prasida) dengan kuatnya (saksi ) Tri Guna. Tri Guna itu adalah Satwan, Rajas dan Tamas. Kalau ketiga guna ini berada pada struktur yang benar maka ia menjadi kekuatan yang luar biasa untuk membawa orang menuju sukses dalam kehidupannya. Struktur yang ideal dari Tri Guna ini apabila struktur ini tersebut didominasi oleh Guna Satwam. Guna Satwam menguasai Rajah dan Tamah. Dalam banten peras disimbolkan dengan benang, lambang Guna Satwam, guna Rajas dilambangkan oleh beras. Ketiga unsur ini ada pada Banten Peras (Suardika, wawancara 22 Desember 2019).

Subagia (wawancara, 12 Desember 2019) Banten lambang kemahakuasaan Tuhan dan manifestasi Tuhan. Banten ini banyak jenisnya, misalnya Banten 
Bantal Siu suatu bentuk budaya sakral keagamaan Hindu yang berwujud kearipan budaya lokal ciri khas Kabupaten Jembrana, khususnya di Kelurahan Baler Bale Agung. Dan didalamnya terkandung nilai-nilai universal global, landasan konsepsinya universal namun aplikasinya tidak bertentangan dengan Tattwa (hakekat kebenaran Veda).

Subagia (wawancara, 12 Desember 2019) Banten Bantal Siu apabila dikaitkan dengan tattwa atau filosofi sesuai dengan bentuknya yaitu terdiri dari dua jenis bantal yang diikat menyerupai purus dan baja. Apabila di bhuana alit menyerupai segitiga, bulat atau simbol dari purusa (laki-laki) dan pradana (wanita) dalam bhuana agung. Dalam hal ini wujud Tuhan sebagai Sanghyang Arda Nare Swari manifestasinya sebagai stana atau lingga Sanghyang Semara dan Ratih di dalam prosesi upacara pawiwahan, lebih jelas lihat gambar berikut.

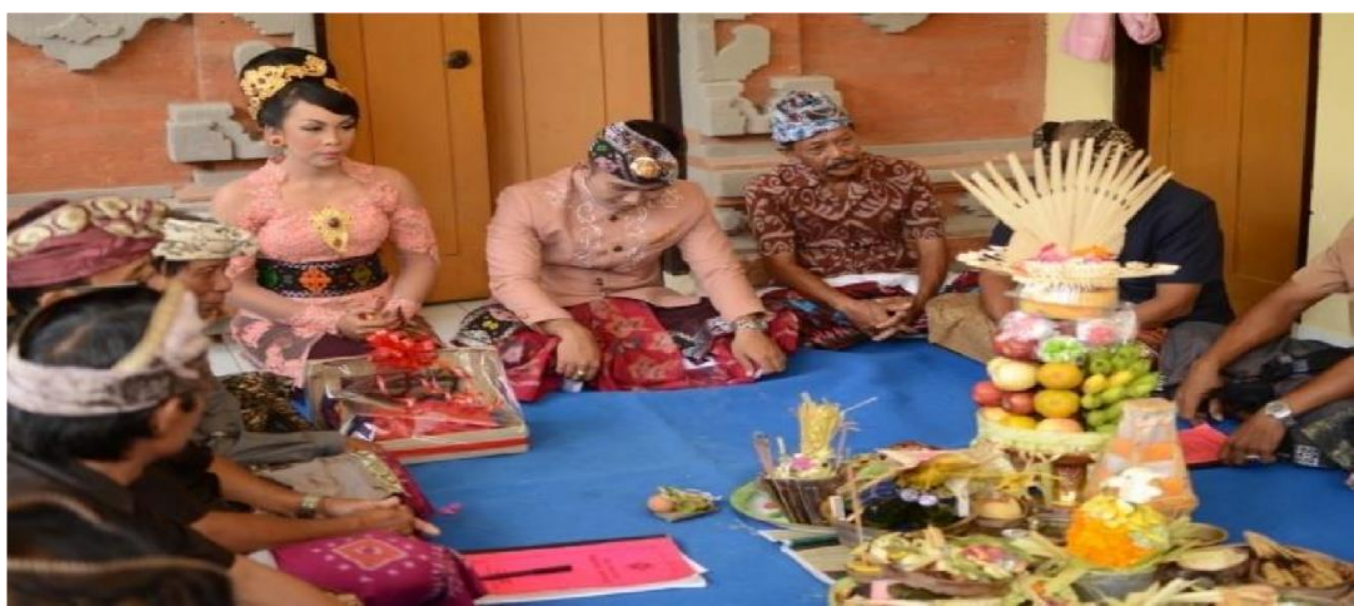

Foto 3

Pelaksanaan Ngeraos (Phala Dara).

(Sumber: Ni Ketut Caturadi Mahyuni, 2019)

Subagia (wawancara, 12 Desember 2019) Dewa Semara dan Dewi Ratih adalah manifestasi Tuhan dalam fungsinya sebagai dewa kasih sayang. Salah satu ciri sifatsifat kedewaan (Satwam) untuk memancarkan kasih sayang yang murni. Sesungguhnya upacara ngeraos (Phala Dara) dalam upacara pawiwahan, ini hanyalah simbolis yang sakral bahwa seseorang telah memiliki sifat-sifat kasih sayang dan telah mampu mengalahkan sifat-sifat kebencian (sifat raksasa rajas dan tamas). Kasih sayang antara Dewa Semara dan Dewi Ratih bukanlah kasih sayang yang didorong oleh hawa nafsu. Kasih dewa dan dewi itu adalah kasih Tuhan itu sendiri yang suci. Demikian juga hendaknya dengan orang yang melangsungkan upacara pawiwahan haruslah didasari dengan cinta dan kasih yang tulus, tidak didasari dengan nafsu belaka, sehingga perkawinan bisa langgeng dan menurunkam anak yang suputra luih sadu gunawan yang sesuai dengan tujuan Grhasta Asrama itu sendiri.

Ariana (wawancara, 21 Desember 2014) menyatakan bila sudah berani mengambil langkah meningkatkan diri kejenjang Grhasta Asrama menyatakan bahwa seseorang itu sudah dewasa. Salah satu ciri orang sudah dewasa adalah mampu menyingkirkan rasa benci pada diri sendiri. Hal inilah yang menyebabkan 
timbulnya istilah dewasa. Kata dewasa ini berasal dari bahasa sansekerta dari akar kata dewa artinya sinar atau terang.

Dalam bentuk genetive menjadi dewasia artinya memiliki terang, dari kata dewasia ini lama-lama menjadi dewasa dalam bahasa Indonesia. Orang yang telah memiliki jiwa yang teranglah dapat disebut dewasa. Jiwa terang ini adalah suatu kemampuan melihat dengan jelas mana yang benar dan mana yang tidak benar. Kalau ada orang yang masih jiwanya digelapkan oleh hawa nafsunya meskipun umur sudah lanjut usia belumlah tepat disebut dewasa. Sehingga belumlah siap untuk meningkat ke Grhasta Asrama.

Apabila diperhatikan dari bahan yang digunakan untuk membuat Bantal Siu itu yang mengandung unsur-unsur sad rasa yaitu manis, pahit, sepet, masam, asin, dan pedas. Hal itu dapat diartikan menanamkan sad rasa kepada orang yang diupacarai sedangkan Ista Dewatanya melalui pemujaan Dewa Semara dan Dewi Ratih (Ariana, wawancara 21 Desember 2019).

Maksud sad rasa dalam upacara pawiwahan khususnya upacara ngeraos (Phala Dara) adalah untuk menggambarkan kematangan jiwa orang yang diupacarai. Ini artinya seseorang yang disebut memiliki jiwa yang matang apabila sudah pernah mengalami berbagai rasa kehidupan. Pahit getirnya kehidupan didunia ini sudah pernah dirasakannya. Orang tidak akan dewasa membawa diri kalau tidak pernah merasakan panas dan dinginnya kehidupan. Mungkin gagalnya berbagai upaya pengentasan kemiskinan yang menyebabkan keributan dalam suatu ikatan perkawinan. Karena orang yang memimpin pengentasan kemiskinan, mungkin orang yang belum pernah merasakan kemiskinan itu sendiri (Ariana, wawancara 21 Desember 2019).

Demikian juga banyak orang merasakan tertekan dalam suatu kerja, karena dipimpin oleh orang yang belum pernah menjadi anak buah sebelumnya. Karena itu orang yang sudah pernah merasakan segala rasa kehidupan ini di dunia ini akan menjadi matang dan semakin dewasa apabila hidup dengan pengalaman dari bawah dan dapat memanfaatkan pengalaman tersebut untuk mendewasakan diri (Ariana, wawancara 21 Desember 2019).

\section{A. Fungsi Religi}

Dalam pelaksanaan Banten Bantal Siu di Kelurahan Baler Bale Agung, Kecamatan Negara, Kabupaten Jembrana tentu mengandung berbagai fungsi tertentu. Fungsi yang dimaksud salah satunya ialah fungsi religi (kepercayaan), karena Banten Bantal Siu merupakan sebuah upakara yang menjadi kepercayaan umat Hindu khususnya di Jembrana.

Fungsi religi yang dimaksud yaitu : (1) Meningkatkan kepercayaan dalam hidup berumah tangga (Grhasta Asrama), (2) Mengharmoniskan pasangan dalam hidup berumah tangga (Grhasta Asrama), (3) Meningkatkan pengabdian istri terhadap suami dalam hidup berumah tangga (Grhasta Asrama), dan (4) Mengingatkan umat agar selalu memperhatikan dan tidak melupakan tradisi yang ada (Suardika, wawancara 22 Desember 201).

\section{B. Fungsi Sosial}

Selain fungsi religi, terdapat juga fungsi sosial yang dapat dilihat pada jalannya prosesi Banten Bantal Siu tersebut. Sosial merupakan suatu hubungan dalam 
masyarakat yang dapat berupa kerjasama ataupun saling membantu. Setiap upacara tercipta dari hubungan antar sesama umat yang saling ketergantungan. Adapun fungsi sosial yang dimaksud pada Banten Bantal Siu ialah: (1) Terjalinnya hubungan kerjasama yang baik antara mempelai berdua pada saat saling menyuapi bantal siu, dan (2) Terdapat hubungan yang baik antar aparat (manggala) dengan keluarga mempelai berdua dan semua umat yang hadir menyaksikan upacara tersebut (Suardika, wawancara 22 Desember 2019).

\section{Fungsi Estetika}

Suardika (wawancara, 22 Desember 201) estetika merupakan unsur keindahan yang dapat terlihat dari suatu benda, simbol, kebudayaan, kegiatan, dan sebagainya. Dalam Banten Bantal Siu terdapat pula fungsi estetika yaitu antara lain: (1) Keindahan dalam kepercayaan akan sebuah Banten Bantal Siu pada saat mempelai berdua saling menyuapi, (2) Jika diperhatikan dengan seksama, keindahan berikutnya dapat terlihat pada Banten Bantal Siu yang tersusun rapi sebuah paso kuningan, diatas paso kuningan berisi dua buah bantal. Bantal yang satu berisi tujuh belas buah yang diikat ujungnya mengerucut segitiga dihiasi warna putih. Dan satunya lagi berisi enam belas buah diikat ujungnya dibusung tagel dihiasi wastra kuning keduanya dialasi dengan kain wali dan diikat dengan benang tridatu, makna dari benang tridatu yaitu tiga unsur kekuatan dari Brahma, Wisnu, dan Siwa. Disampingnya diisi temu-temuan, kelapa dibakar (nyuh metunu), pisang saba dibakar (biu metunu), tipat sirikan, sate lima buah, karangan atau bakaran (pengunyaan). Untuk menambah keindahan yang dapat menarik perhatian umat dan menginspirasi umat agar kedepannya dalam pembuatan banten apapun itu dilakukan dengan baik, bahan dasarnya haruslah bahan yang baik serta disesuaikan dengan kemampuan dan keikhlasan (sattwika).

\section{Fungsi Pendidikan}

Pendidikan Agama Hindu dalam perkembangannya harus dilaksanakan dengan baik, berulang-ulang, berkesinambungan, dan tentunya selalu dikaitkan pada bidang-bidang tertentu dengan bimbingan dari seseorang yang dikatakan mengetahui yang disebut sebagai guru. Tentang pentingnya pendidikan dapat diperhatikan pada sloka Reg.Veda X.32.7 berikut ini:

Aksetravit ksetravidam hyaprat sa paiti ksetravidanusistah etad van bhadram anusasanasya ta sruti vindatyas njasinam

Terjemahan:

Orang yang tidak mengenal suatu tempat bertanya kepada orang yang mengetahuinya. Ia meneruskan perjalanan, dibimbing oleh orang yang tahu. Inilah manfaat pendidikan. Ia menemukan jalan yang lurus.

Demikian pentingnya pendidikan dalam menjalankan kewajiban hidup di dunia. Pendidikan sangat bermanfaat jika dipergunakan dengan baik begitu pula sebaliknya. Dalam melaksanakan prosesi Banten Bantal Siu fungsi pendidikan 
menuntun kehidupan dan mendidik mempelai berdua khususnya, agar dalam suatu perkawinan dapat berjalan dengan harmonis dan tenteram. Sehingga dalam perkawinan mempelai berdua tahu bagaimana cara bertingkah laku supaya tidak bertentangan dengan ajaran Dharma.

\section{PENUTUP}

Upacara Pawiwahan untuk pengesahan mempelai berdua dipergunakan sarana upakara yaitu Banten Bantal Siu. Dimana sarana ini merupakan sarana utama atau pokok dari upacara Pawiwahan khususnya di Kelurahan Baler Bale Agung, dan umumnya di Kabupaten Jembrana. Adapun isi dari Bantal Siu adalah sebuah paso kuningan, diatas paso kuningan berisi dua buah bantal. Bantal yang satu berisi tujuh belas buah yang diikat ujungnya mengerucut segitiga dihiasi wastra putih. Dan satunya lagi berisi enambelas buah diikat ujungnya dibusung tagel dihiasi wastra kuning keduanya dialasi dengan kain wali dan diikat dengan benang tridatu, makna dari benang tridatu yaitu tiga unsur kekuatan dari Brahma, Wisnu, dan Siwa. Disampingnya diisi teтu-temuan, kelapa dibakar (nyuh metunu), pisang saba dibakar (biu metunu), tipat sirikan, sate lima buah, karangan atau bakaran (pengunyaan). Dipergunakannya Bantal Siu sebagai sarana pengeraos (Phala Dara) itu dikarenakan Bantal Siu adalah simbol dari Sad Rasa yaitu manis, pahit, asam, asin, pedas, sepet, yang melambangkan kehidupan Grhasta Asrama atau hidup berumah tangga.

Berkenaan dengan setiap pelaksanaan suatu kegiatan tentu terdapat fungsi yang terkandung didalamnya. Fungsi Banten Bantal Siu, yaitu: (1) Meningkatkan kepercayaan dalam hidup berumah tangga (Grhasta Asrama), (2) Mengharmoniskan pasangan dalam hidup berumah tangga (Grhasta Asrama), (3) Meningkatkan pengabdian istri terhadap suami dalam hidup berumah tangga (Grhasta Asrama), dan (4) Mengingatkan umat agar selalu memperhatikan dan tidak melupakan tradisi yang ada.

\section{DAFTAR PUSTAKA}

Arikunto, Suharsini. 2002. Prosedur Penelitian. Edisi Revisi 5. Jakarta: PT. Rineka Cipta.

Basrowi dan Sukidin. 2002. Metode Penelitian Kualitatif, Perspektif Mikro. Surabaya: Insan Cendikia.

Bugin, Burhan. 2006. Metodologi Penelitian Kualitatif. Jakarta : PT Raja Grafindo Persada.

Bajrayasa, I Gde. 1981. Acara I. Proyek Pembinaan Mutu Guru Agama Hindu dan Budha Departemen Agama RI.

Basrowi dan Sukidin. 2002. Metode Penelitian Kualitatif, Perspektif Mikro. Surabaya: Insan Cendikia. 
Bungin, Burhan. 2006. Metodologi Penelitian Kualitatif, Jakarta: $\quad$ PT RajaGrafindo Persada.

Dewanto, 2005. Rg Veda Samhita: Mandala VIII, IX, X. Surabaya: Paramita.

Hasan, Iqbal.2002. Metodologi Penelitian dan Aplikasinya. Jakarta: Ghalia Indonesia.

Imron Arifin. 1996. Penelitian Kualitatif dalam ilmu-ilmu Sosial dan Keagamaan. Malang: Kalimasahada.

Kajeng, I Nyoman. dkk.1999. Sarasamuccaya: Dengan Teks Bahasa Sansekerta dan Jawa Kuna. Surabaya: Paramita.

Kruyt, 1949. Tentang Asal Mula Relegi. Surabaya : Paramitha

Kahmad, Dadang. 2002. Sosiologi Agama. Bandung: PT. Remaja Rosdakarya.

Karda, I Made. 2007. Sistem Pendidikan Agama Hindu. Surabaya: PT. Paramitha.

Keriana, I Ketut.2007. Prosesi Upakara dan Yadnya.Denpasar :Rhika Dewata.

Koentjaraningrat, 1997.Antropologi Budaya. Jakarta :Rineka Cipta.

Miles B. Matthew; dan Huberman A. Ichael. 1992. Analisis Data Kualitatif: Buku Sumber Tentang Metode-Metode Baru. Jakarta: Universitas Indonesia Pres. 80 Margono, 1996. Metodologi Penelitian Pendidikan.

Jakarta: Rineka Cipta.

Malo. 1997. Metodologi Penelitian Kualitatif. Jakarta: Rineka Cipta.

Mulyana D. 2001. Metodologi Penelitian Kualitatif. Bandung: Remaja Rosda Karya.

Moleong, Lexy.J. 2002. Metodologi Penelitian Kualitatif. Bandung: PT. Remaja

Rosdakarya.

Nazir, Moh. 1988. Metode Penelitian. Jakarta: Ghalia Indonesia

Nottingham, Elizabeth K. 2002. Agama Dan masyarakat: Suatu Pengantar Sosiologi. Jakarta: PT. Raja Grafindo Persada.

Paramita, I Gusti Agung. 2018. Bencana, Agama dan Kearifan Lokal. (Jurnal Dharmasmrti Vol. 1 No. 18, Denpasar Jurnal Ilmu Agama dan

Kebudayaan Universitas Hindu Indonesia, 2018).

Purwadarminta, 1984. Tentang Konsep dan Rancangan. Jakarta : Balai Pustaka.

Pals, Daniel. L. 2002. Dekonstruksi Kebenaran. Yogyakarta : IRCisoR.

Pasek Swastika, Ketut, 2010.Grhasta Asrama. Panakom: Denpasar. 
Pudja, Gede. 2002. Kitab Suci Bhagawad Gita: Dengan Teks Bahasa Sansekerta \& Bahasa Indonesia. Surabaya: Paramita.

Pudja G. dan Sudharta, Tjokorda Rai. 2002. Manawa Dharma Çastra: Manu Dharma Çastra atau Weda Smrti Compendium Hukum Hindu. Jakarta: Felita Nursatama Lestari. 